\title{
Micropollutants in treated wastewater
}

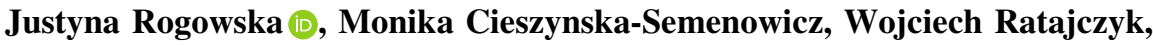 \\ Lidia Wolska
}

\begin{abstract}
Compounds such as pharmaceuticals, or personal care products are only partially removed in wastewater treatment processes. Large number of these compounds and their degradation products is out of any control. A small number of compounds are covered by legal regulations. Among the compounds non-regulated by law, the target compounds, as well as non-target compounds can be distinguished. In the scientific literature, number of reports on various target compounds' determination is increasingly growing. This paper provides an up-to-date review on micropollutants present in treated wastewater and their concentrations found in literature in the years 2015-2019. Because the obtained results of chemical analyses do not adequately reflect the risks to ecosystems and consequently humans, the results of chemical analyses have been supplemented by a review of ecotoxicological studies. In addition, legal issues linked to contamination of treated wastewater and research related to identification of non-target compounds in treated effluents have been discussed.
\end{abstract}

Keywords Aquatic environment - Ecotoxicity ·

Microorganic pollutants - Wastewater .

Wastewater treatment plants (WWTPs)

\section{INTRODUCTION}

The global socioeconomic development generates a stream of substances (some of them are new), which almost immediately occur in the environment. It has been estimated, that the chemical industry currently produces more than 70000 different chemical products, with an estimated worldwide sales value of $\$ 5000$ billion (Asthana 2014). Many of these substances released into the aquatic environment pose a serious risk for the environment and for human health.

In the last decade, the political awareness of water quality issues has grown substantially in the European Union (EU), as wastewater treatment plants (WWTPs) have been identified as a major point source pollution (Corominas et al. 2013). Conventional WWTPs are incapable of eliminating many compounds found in wastewater. In last decades, much attention has been paid to analytics compounds such as endocrine-disrupting chemicals (EDCs) or pharmaceuticals. Treated wastewater released from WWTPs can be discharged to the receiving bodies such as surface waters (e.g., rivers, lakes) or, preferably from the end of the last century in some regions, sea waters. As a consequence, many compounds found in wastewater effluents and/or their metabolites and transformation products are detected in surface waters and to great concern of scientists, end up in marine environment. The properties of these substances and their impact on the environment and human health are often unknown. Knowledge about the long-term effects of exposure to a mixture of pollutants present in the environment at low concentration levels is still limited (HELCOM 2003). It should be noted that only substances that are commonly found in the environment at a significant concentration levels and at the same time posing a threat to the environment and/or human health are covered by legal norms (compounds regulated by law). For example, according to Art. 16 of the Water Framework Directive is the list of priority substances that pose a threat to the aquatic environment. This risk is assessed according to a procedure based on scientific principles. To include the substance in the list of priority substances in the field of water policy, a reliable scientific evidence must be provided 'regarding the intrinsic hazard of the substance concerned, and in 


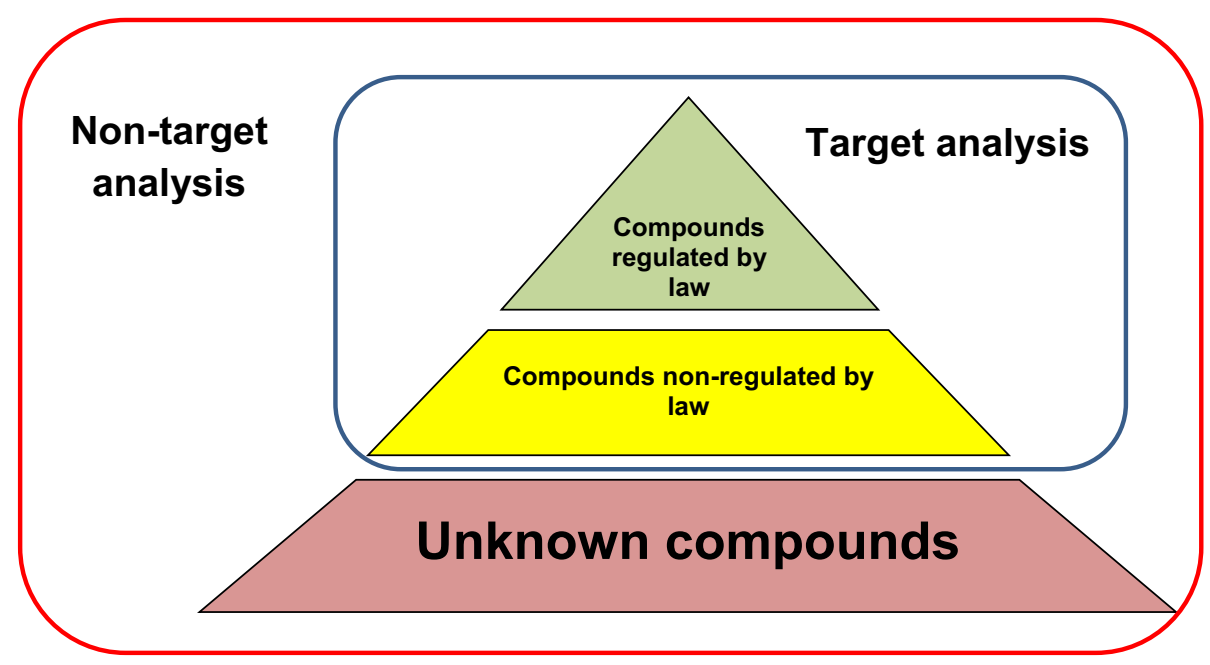

Fig. 1 Types of compounds found in the aquatic environment

particular its aquatic ecotoxicity and human toxicity via aquatic exposure routes, and evidence from monitoring of widespread environmental contamination, and other proven factors which may indicate the possibility of widespread environmental contamination, such as production or use volume of the substance concerned, and use patterns' (WFD 2000). Therefore, only a small number of compounds is covered by the legal regulations (Fig. 1). These compounds are systematically monitored in the environment, e.g., polychlorinated biphenyls (PCBs). But large number of compounds and their degradation products fall outside of any control. Among the non-regulated by law compounds, compounds which can be expected in the wastewater due to their considerable emission into the environment can be distinguished. Currently, these are mostly pharmaceuticals. The second and most numerous group constitutes unknown compounds. The number of potential contaminants is essentially endless. For example, over 10000 prescription drugs and about 300 over-thecounter drugs are currently in use and produced in USA and may be released to the environment during processing or use (Dong et al. 2013). Furthermore, degradation and transformation products of certain substances in the environment can have unknown structure and properties. The newly formed, emerging, products may pose a greater threat to the environment (and organisms living in it) than the parent compounds (Garnaga 2012). It should also be noted that in an aquatic environment, substances are present in the mixtures and still there is a lack of comprehensive knowledge about the effects of chemicals, their combinations/mixtures on the environment and human health.

The aim of our study was to review literature on the presence of contaminants in treated sewage and their highest concentrations. We point out that the research articles on the pollutants present in wastewater are primarily based on target analysis. On the other hand, there are very few research papers covering problems related to identification of non-target compounds in treated effluents. What is more, we have indicated threats to aquatic ecosystems as a consequence of the presence of toxic compounds and endocrine active compounds in treated effluents on the basis of ecotoxicological studies. The information has been supplemented with legal issues linked to contamination of treated wastewater and research (and problems) related to identification of non-target compounds in wastewater effluents.

\section{METHODS}

In this review, we have focused on recent studies published from years 2015-2019. We searched Scopus database, which provides access to STM journal articles and the references included in those articles. We entered a combination of terms/keywords such as 'micropollutants,' 'concentration,' 'effluents,' and 'wastewater' into search box and sorted results by relevance. In literature, we were looking for the highest measured and reported concentrations of compounds in effluents from conventional wastewater treatment plants worldwide, collecting a mixture of domestic and industrial wastewater. In our review, we do not include concentrations of compounds found in effluents coming from industry alone (e.g., pharmacy, slaughter house, pulp and paper, textiles, hospital effluents), wastewater influents, potable water, surface waters. Due to the fact that for each year we found over 600 references and the resources are virtually infinite, the present 
review is a selection of just some of the major studies. Our selection of micropollutants thus must focus on chemicals that in our opinion pose the greatest threat to environment is due to the following: high measured concentrations, significant ecotoxicity, frequency of detection, and unsatisfactory removal efficiency. For the micropollutants with the highest concentrations detected, we compiled ecotoxicity data based on laboratory results.

The occurrence of micropollutants in wastewaters was revised by many authors: Das et al. (2017), Jiang et al. (2013), Luo et al. (2014), Petrie et al. (2015), and Ratola et al. (2012). These reviews mainly indicate compounds detected in treated wastewaters, and efficacy and methods of wastewater treatment. Therefore, in our review we decided to fill in the knowledge gap and added ecotoxicity data for the micropollutants with the highest measured concentrations mentioned in literature.

\section{MICROPOLLUTANTS IN TREATED WASTEWATER}

\section{Legal aspects of contaminants in treated wastewater}

In Europe, the state of the aquatic environment is controlled by legislation outlined by the European Commission. Directive 2000/60/EC setting out the framework for community action in the field of water policy has reformed the water quality policy of the community, and is the first attempt to move towards ecosystem-based management that should ensure the good ecological status (WFD 2000; Corominas et al. 2013). Its aim is the prevention of water pollution within the European Union through such steps as identifying the pollutants which pose the greatest risks to or via the water environment. The priority under this directive is to identify and eliminate the sources of harmful emissions. A supplementary of WFD is Directive 2008/105/EC of the European Parliament and of the Council of 16 December 2008 on environmental quality standards in the field of water policy and Directive 2013/39/EU of the European Parliament and of the Council of 12 August 2013 amending Directives 2000/60/EC and 2008/105/EC as regards priority substances in the field of water policy which includes the list of 45 priority substances. Enactment in 2008 Directive 2008/56/EC of the European Parliament and of the Council of 17 June 2008 establishing a framework for community action in the field of marine environmental policy called the Marine Strategy Framework Directive (MSFD), widens the scope of the European Union (EU) legal framework to cover the marine environment for a new EU-integrated ecosystem policy for the protection of the water environment.
Requirements for the quality of wastewater discharged from the plant are included in Council Directive 91/271/ EEC of 21 May 1991 concerning urban wastewater treatment. Directive determines the inter alia requirements for discharges from urban wastewater treatment plants, including emission limit values for these. Treated wastewater discharged from the WWTPs are characterized only by chemical and biochemical oxygen demand and total suspended solids. In the case that treated effluents from WWTPs are discharged to sensitive areas which are prone to eutrophication, provisions of the Directive require also the determination of total nitrogen and total phosphorus. Specifically, WWTPs effluents are controlled by a 'combined' approach of emission limit values, load reduction, and environmental quality standards, along with the restriction or phasing out of particularly priority and dangerous priority substances under these Directives (Corominas et al. 2013).

Analyzing the provisions of Directives it should be noted that:

1. The European Commission carries out a regular review of a list of priority substances in the field of water policy. The European Commission also prepares a list of observational material. Substances to be placed on the watch list are selected from among those for which the available information suggests that they may represent the significant risk to the aquatic environment or through, and for which monitoring data are insufficient (WFD 2000). However, what has already been mentioned, for the relatively small number of organic pollutants in the environment changes are fully understood, and the majority of these impurities cannot be identified (HELCOM 2003).

2. Treated wastewater discharged from the WWTPs are characterized by total nitrogen/phosphorus, total suspended solids, and chemical/biochemical oxygen demand.

3. Legal provisions do not take into account the interactions between pollutants (even those included in the list of priority substances) such as synergism, additivity, or antagonism.

\section{Contaminants in treated wastewater}

Conventional secondary processes (activated sludge and trickling filters) represent the most extensively used method of wastewater purification. However, these processes fail to remove large number of chemical compounds. For example, some pharmaceuticals such as paracetamol or ibuprofen are efficiently removed through conventional treatment methods ( $>99 \%$ and $72-100 \%$, respectively) (Ratola et al. 2012; Luo et al. 2014), while 
others, such as sulfamethazine or carbamazepine are being removed from wastewater less effectively $(13 \%$ and 7-23\%, respectively) (Ratola et al. 2012). As a result, compounds belonging to groups of pharmaceuticals, personal care products, surfactants, biocides, or flame retardants may be released to surface waters (rivers, lakes, or coastal waters) (Petrie et al. 2015). Many pharmaceuticals may undergo various transformations in the environment, animal, or human body. Pharmaceuticals can be completely or partially metabolized in the organisms, what may lead to the unchanged parent drugs and the produced metabolites excretion via urine and/or feces (Ribeiro et al. 2016). Particular interest is also aroused by transformation products that can be formed during water disinfection and wastewater treatment, as well as due to various processes occurring in natural waters such as biodegradation, photodegradation, hydrolysis (Nikolaou 2013; Deeb et al. 2017). What is more, compounds found in wastewater can degrade and/or react with other compounds in the environment re-emitting products of higher toxicity than the original compounds. The determination of the toxic effects of pharmaceuticals, their transformation products and mixtures in the environment, is a subject requiring urgent attention, and a great challenge for scientists. Moreover, they are present in trace concentrations (Nikolaou 2013). Number of papers related to multiresidue analytical methodologies has increased over recent years; however, most of them are focused on target analysis methods (Kotowska et al. 2014; Gurke et al. 2015; García-Galán et al. 2016; Knopp et al. 2016; Roberts et al. 2016; Madikizela and Chimuka 2017; Petrie et al. 2017; Wang et al. 2018).

Potential risks of adverse effects caused by effluents from WWTPs to aquatic environments are influenced by volume of effluent, concentration of compounds in wastewater, the water flow rate of the receiving river, weather conditions, and probably other factors that affect dissipation through dilution and/or degradation. The compounds detected in effluents from sewage-treatment plants at concentrations above $1 \mu \mathrm{g} / \mathrm{L}$ and published in the period of 2015-2019 are listed in Table 1. For our list, we established a limit of concentration recognized as environmentally relevant in prioritization of contaminants in wastewaters (Blum et al. 2017; Gros et al. 2017).

The compounds of the highest concentrations in treated effluents are antidepressant citalopram, antiepileptic gabapentin, anti-inflammatory tramadol and diclofenac, and antiretroviral drugs such as lamivudine, zidovudine, efavirenz, and darunavir. It is worth mentioning that one metabolite, $\mathrm{N}$-acetyl-4-aminoantipyrine, a metabolite of dipyrone was found in effluent at concentration as high as $25.03 \mu \mathrm{g} / \mathrm{L}$. Among other compounds with high concentrations also artificial sweeteners acesulfame and sucralose are detected at concentrations of $22.50 \mu \mathrm{g} / \mathrm{L}$ and $18.80 \mu \mathrm{g} /$ L, respectively (Das et al. 2017; Tolouei et al. 2019). More than $95 \%$ of ingested sucralose is excreted in urine, $<2 \%$ is degraded at wastewater treatment plants, and the rest is exported unaltered with effluent (Amy-Sagers et al. 2017). Also X-ray contrast media such as iopamidol, iopromide, iomeprol are not effectively eliminated from the wastewater (Santos et al. 2010).

Other micropollutants, which are detected in wastewater effluents, are nanoparticles (NP). Trace amounts of nanoparticles exist naturally in environment; however, recently, their incorporation in technology, medicine, and in many domestic consumer products, contribute to their presence in wastewaters and their inevitable release to aquatic ecosystems. The definition of NP stating that it is any material with at least one dimension in the range of $1-100 \mathrm{~nm}$ is very broad. Therefore, many substances such as metals (Ag, $\mathrm{Zn}, \mathrm{Ni}, \mathrm{Fe}, \mathrm{Cu})$; metal oxides $\left(\mathrm{TiO}_{2}, \mathrm{Fe}_{3} \mathrm{O}_{4}\right.$, $\mathrm{SiO}_{2}, \mathrm{CeO}_{2}$, and $\mathrm{Al}_{2} \mathrm{O}_{3}$ ); non-metals (silica and quantum dots); forms of carbon (nanotubes, fullerene, graphene) exist in nanoscale (Madeła et al. 2016). Therefore, even though concentration of nanoscale fragments noted in effluent was significantly high $(550 \pm 130 \mu \mathrm{g} / \mathrm{L})$, the effluent content of specific nanoparticles is lower: $5.5 \mu \mathrm{g} / \mathrm{L}$ for $\mathrm{Ag}-\mathrm{NP}, 19.1 \mu \mathrm{g} / \mathrm{L}$ for fullerene $\mathrm{C}_{60}, 1.65 \mu \mathrm{g} / \mathrm{L}$ for fullerene $\mathrm{C}_{70}$, and $31.9021 \mu \mathrm{g} / \mathrm{L}$ for $N$-methylfulleropyrrolidine $\mathrm{C}_{60}$ (Farré et al. 2010; Yang et al. 2012).

Industrial chemicals, such as $1 \mathrm{H}$-benzotriazole and 4-methyl-1H-benzotriazole, used in a wide range of commercial and industrial applications such as corrosion inhibitors, dishwasher detergents, and antifreezes are also among high-concentration micropollutants of $22.1 \mu \mathrm{g} / \mathrm{L}$ and $24.3 \mu \mathrm{g} / \mathrm{L}$ content, respectively (Deeb et al. 2017).

Out of all the groups of compounds identified and determined in treated effluents, much attention is being paid to the presence of most commonly prescribed antibiotics (ciprofloxacin, doxycycline, norfloxacin, trimethoprim, and sulfamethoxazole) and analgesics/antiinflammatory pharmaceuticals such as ibuprofen, naproxen, or diclofenac (Deblonde et al. 2011). In addition, in treated wastewater, often triclosan, an ingredient in personal hygiene and household products such as soaps, toothpaste, mouthwash, deodorants, detergents, and disinfecting lotions is detected (Kotowska et al. 2014).

\section{Non-target analysis}

Target analysis is focused on identification and quantification of certain compounds. However, quantification of target chemicals in the treated wastewater is insufficient for risk assessment, due to introduction of wastewater into the environment. The wastewater may contain many unknown substances. Screening of unknown organic compounds 
Table 1 The maximum concentrations of most often determined compounds in effluents from WWTPs, arranged in order of decreasing concentration

\begin{tabular}{|c|c|c|c|}
\hline Group of compounds & Identified compounds & $\begin{array}{l}\text { Highest } \\
\text { concentration } \\
\text { determined }(\mu \mathrm{g} / \mathrm{L})\end{array}$ & References \\
\hline Antidepressant agents & Citalopram & 840 & Cunha et al. (2019) \\
\hline Nanoparticles & $\begin{array}{l}\text { Nanoscale fragments containing } \\
70-85 \% \text { of carbon, low amounts } \\
\text { of oxygen and heavy metals }\end{array}$ & $550 \pm 130$ & Hu et al. (2018) \\
\hline Antiepileptics & Gabapentin & 79.86 & Oliveira et al. (2015) \\
\hline Analgesics/anti-inflammatories & Tramadol & 59.05 & Petrie et al. (2015) \\
\hline Antiretroviral agents & Lamivudine & $55.76 \pm 5.48$ & Ngumba (2018) \\
\hline Antiretroviral agents & Zidovudine & $37.14 \pm 2.56$ & Ngumba (2018) \\
\hline Antiretroviral agents & Efavirenz & $34 \pm 2.8$ & Abafe et al. (2018) \\
\hline $\mathrm{H} 2$-receptor antagonists & Valsartan & 28.22 & Gurke et al. (2015) \\
\hline Metabolites & $\mathrm{N}$-acetyl-4-aminoantipyrine & 25.03 & Evgenidou et al. (2015) \\
\hline Industrial chemicals & 4-Methyl-1H-benzotriazole & 24.30 & Deeb et al. (2017) \\
\hline Analgesics/anti-inflammatories & Diclofenac & 23.50 & $\begin{array}{l}\text { Madikizela and Chimuka. } \\
\text { (2017) }\end{array}$ \\
\hline Artificial sweetener & Acesulfame & 22.50 & Das et al. (2017) \\
\hline Industrial chemical & 1H-benzotriazole & 22.10 & Deeb et al. (2017) \\
\hline Artificial sweetener & Sucralose & 18.80 & Tolouei et al. (2019) \\
\hline Angiotensin receptor antagonist & Irbesartan & 17.90 & Kårelid et al. (2017) \\
\hline Contrast media & Iopromide & 17.90 & Qi et al. (2015) \\
\hline Antiretroviral agents & Darunavir & $17 \pm 0.55$ & Abafe et al. (2018) \\
\hline Contrast media & Iopamidol & 16.29 & Völker et al. (2017) \\
\hline Anti-anxiety agents & Bromazepam & 15.54 & Cunha et al. (2019) \\
\hline Analgesics/anti-inflammatories & Naproxen & 14.40 & $\begin{array}{l}\text { Madikizela and Chimuka. } \\
\text { (2017) }\end{array}$ \\
\hline Analgesics/anti-inflammatories & Acetaminophen & 11.73 & Petrie et al. (2015) \\
\hline Contrast media & Diatrizoate & 11.73 & Völker et al. (2017) \\
\hline Stimulants & Caffeine & 11.45 & Gros et al. (2017) \\
\hline Metabolites & Metronidazole-OH & 11.34 & Evgenidou et al. (2015) \\
\hline Contrast media & Iomeprol & 11.25 & Völker et al. (2017) \\
\hline Antidiabetic drugs & Metformin & 10.35 & Das et al. (2017) \\
\hline Diuretics & Furosemide & 9.96 & Papageorgiou et al. (2016) \\
\hline Analgesics/anti-inflammatories & Nimesulide & 9.73 & Papageorgiou et al. (2016) \\
\hline Metabolites & 4-Aminoantipyrine & 9.29 & Evgenidou et al. (2015) \\
\hline Metabolites & 4-Methylaminoantipyrine & 9.25 & Evgenidou et al. (2015) \\
\hline Analgesics/anti-inflammatories & Ibuprofen & 9.20 & Gros et al. (2017) \\
\hline Metabolites & Erythromycin- $\mathrm{H}_{2} \mathrm{O}$ & 7.84 & Evgenidou et al. (2015) \\
\hline Anti-anxiety agents & Oxazepam & 7.43 & Cunha et al. (2019) \\
\hline Contrast media & Diatrizoic acid & 7.03 & Ribbers et al. (2019) \\
\hline Metabolites & $4^{\prime}$-Hydroxy diclofenac & 7.02 & García-Galán et al. (2016) \\
\hline Beta-blockers & Metoprolol & 5.76 & Gurke et al. (2015) \\
\hline Metabolites & Erythro/threo-hydrobupropion & 5.70 & Evgenidou et al. (2015) \\
\hline Metabolites & o-desmethylvenlafaxine & 5.50 & Evgenidou et al. (2015) \\
\hline Antidepressant agents & Venlafaxine & 5.50 & Roberts et al. (2016) \\
\hline Analgesics/anti-inflammatories & Codeine & 5.27 & Petrie et al. (2015) \\
\hline Analgesics/anti-inflammatories & Ketoprofen & 5.25 & Oliveira et al. (2015) \\
\hline Antibiotics & Cephalexin & 5.07 & Deeb et al. (2017) \\
\hline Flame retardants & Tri-(2-chloroisopropyl)phosphate & 4.90 & Gros et al. (2017) \\
\hline
\end{tabular}


Table 1 continued

\begin{tabular}{|c|c|c|c|}
\hline Group of compounds & Identified compounds & $\begin{array}{l}\text { Highest } \\
\text { concentration } \\
\text { determined }(\mu \mathrm{g} / \mathrm{L})\end{array}$ & References \\
\hline Analgesics/anticonvulsant & Carbamazepine & 4.61 & Deeb et al. (2017) \\
\hline Flame retardants & Tris-(2-butoxyethyl)phosphate & 4.60 & Gros et al. (2017) \\
\hline Sunscreen Agent & 4-Benzophenone & 4.31 & Petrie et al. (2015) \\
\hline $\begin{array}{l}\text { Preservative and anti-infective } \\
\text { agent }\end{array}$ & Triclosan & 4.26 & Deeb et al. (2017) \\
\hline Industrial chemicals & 2,4,7,9-Tetramethyl-5-decyne-4,7-diol & 4.20 & Blum et al. (2017) \\
\hline Antiepileptics & Lamotrigine & 4.12 & Oliveira et al. (2015) \\
\hline Diuretics & Theobromine & 4.01 & Oliveira et al. (2015) \\
\hline Antiretroviral agents & Lopinavir & $3.8 \pm 0.35$ & Abafe et al. (2018) \\
\hline Metabolites & $\begin{array}{l}\text { 10,11-Dihydro-trans-10,11-dihydroxy- } \\
\text { carbamazepine }\end{array}$ & 3.60 & Evgenidou et al. (2015) \\
\hline Metabolites & Carbamazepine-10,11-epoxide & 3.58 & Evgenidou et al. (2015) \\
\hline Antiretroviral agents & Raltegravir & $3.5 \pm 1.3$ & Abafe et al. (2018) \\
\hline Diuretics & Hydrochlorothiazide & 3.42 & Oliveira et al. (2015) \\
\hline Transformation product (oxidation) & Carboxy-Acyclovir & 3.40 & Knopp et al. (2016) \\
\hline Beta-blockers & Sotalol & 3.33 & Roberts et al. (2016) \\
\hline Antibiotics & Sulfamethoxazole & 3.25 & Oliveira et al. (2015) \\
\hline Bronchodilator & Theophylline & 3.17 & Petrie et al. (2015) \\
\hline Lipid regulator & Bezafibrate & 3.12 & Gros et al. (2017) \\
\hline Metabolites & Cotinine & 3.10 & Evgenidou et al.,2015) \\
\hline Beta-blockers & Atenolol & 2.87 & Deeb et al. (2017) \\
\hline Angiotensin receptor antagonist & Telmisartan & 2.75 & Gurke et al. (2015) \\
\hline $\mathrm{H} 2$-receptor antagonists & Cimetidine & 2.61 & Petrie et al. (2015) \\
\hline Metabolites & Metoprolol acid & 2.51 & Evgenidou et al. (2015) \\
\hline Antibiotics & Trimethoprim & 2.40 & Deeb et al. (2017) \\
\hline Flame retardant & Tris(2-butoxyethyl)phosphate & 2.40 & Blum et al. (2017) \\
\hline Antibiotics & Penicillin G & 2.22 & Deeb et al. (2017) \\
\hline Industrial chemicals & Tolyltriazole & 2.20 & Knopp et al. (2016) \\
\hline Antibiotics & Levofloxacin & 2.19 & Deeb et al. (2017) \\
\hline Analgesics & Salicylic acid & 2.18 & Evgenidou et al. (2015) \\
\hline Angiotensin receptor antagonist & Candesartan & 1.99 & Gurke et al. (2015) \\
\hline Antiretroviral agents & Nevirapine & $1.9 \pm 0.68$ & Abafe et al. (2018) \\
\hline Metabolites & 10-Hydroxy-10,11-dihydrocarbamazepine & 1.90 & Evgenidou et al. (2015) \\
\hline Psychoanaleptics & Desmethylvenlafaxine & 1.87 & Oliveira et al. (2015) \\
\hline Metabolites & Guanylurea & 1.86 & Evgenidou et al. (2015) \\
\hline Antibiotics & Clarithromycin & 1.79 & Deeb et al. (2017) \\
\hline Lipid-regulators & Simvastatin & 1.74 & Papageorgiou et al. (2016) \\
\hline Analgesics/anti-inflammatories & Aminopyrine & 1.68 & Deeb et al. (2017) \\
\hline Anti-allergic agents & Fexofenadine & 1.61 & Archer et al. (2017) \\
\hline Metabolites & Benzoylecgonine & 1.60 & Petrie et al. (2015) \\
\hline Metabolites & $4^{\prime}$-Hydroxy aceclofenac & 1.60 & Evgenidou et al. (2015) \\
\hline Flame retardant & Tris(1-chloro-2-propyl)phosphate & 1.60 & Blum et al. (2017) \\
\hline Antiretroviral agents & Ritonavir & $1.50 \pm 0.053$ & Abafe et al. (2018) \\
\hline Antibiotics & Norfloxacin & 1.50 & Deeb et al. (2017) \\
\hline Phytosterols & Beta-sitosterol & 1.50 & Wang et al. (2018) \\
\hline Metabolites & $O$-Desmethyltramadol & 1.47 & Archer et al. (2017) \\
\hline Industrial chemicals & Methylindole & 1.42 & Deeb et al. (2017) \\
\hline
\end{tabular}


Table 1 continued

\begin{tabular}{llll}
\hline Group of compounds & Identified compounds & $\begin{array}{l}\text { Highest } \\
\text { concentration } \\
\text { determined }(\mu \mathrm{g} / \mathrm{L})\end{array}$ & References \\
\hline Beta-blockers & Labetalol & 1.40 & Oliveira et al. (2015) \\
Solvents & 2-Butoxyethanol & 1.40 & Wang et al. (2018) \\
Antibiotics & Erythromycin & 1.39 & Petrie et al. (2015) \\
H2-receptor antagonists & Ranitidine & 1.38 & Dasenaki and Thomaidis (2015) \\
Hormones & Progesterone & 1.34 & Deeb et al. (2017) \\
Metabolites & Carboxy-ibuprofen & 1.27 & Evgenidou et al. (2015) \\
Antihistamines & Cetirizine & 1.24 & Papageorgiou et al. (2016) \\
Antiepileptics & Pregabalin & 1.24 & Gurke et al. (2015) \\
Flame retardant/plasticizer & Tris(2-chloroethyl)phosphate & 1.16 & Wang et al. (2018) \\
Antibiotics & Ciprofloxacin & 1.08 & Deeb et al. (2017) \\
Angiotensin receptor antagonist & Eprosartan & 1.04 & Gurke et al. (2015) \\
Analgesics/anti-inflammatories & Lidocaine & 1.00 & Oliveira et al. (2015) \\
\hline
\end{tabular}

present in the treated wastewater allows for the identification of particularly hazardous compounds and can be useful for maintaining the suitable purity of surface water (Kotowska et al. 2012). Most scientific research focuses on the determination of specific compounds. There are only few reports in literature on the identification of non-target contaminants in the treated sewage (Gómez et al. 2009; Kotowska et al. 2012; Hug et al. 2014; Dsikowitzky et al. 2015; Hrubik et al. 2016; Blum et al. 2017; Gros et al. 2017). This is due to the fact that the analysis of these kinds of contaminants is complicated, time consuming, and represents a real challenge for environmental analysts. Nontarget analysis allows for identification of both known and unknown chemicals. The analytical methods for the detection and quantification of non-target contaminants (in group of organic compounds) are generally based on separation methods, particularly gas chromatography (GC) or/ and liquid chromatography (LC) coupled with a potential instrument for identification such as mass spectrometry (MS) (Gómez et al. 2009). The choice of the applied method is associated with physicochemical properties of the target analytes. Liquid chromatography-high-resolution mass spectrometry (LC-HRMS) offers the possibility to detect hundreds of polar and non-polar compounds without pre-selection of analytes (Hug et al. 2014).

In general for the analysis of pharmaceuticals in wastewater, it is appropriate to use GC; however, degradation products of some of those compounds may be thermolabile and decompose during GC analysis as it is in the case of carbamazepine and its degradation product iminostilbene (Gómez et al. 2009). The compound's spectrum that is detectable with the use of GC-MS method is restricted to volatile, low-molecular weight non-polar to semi-polar organic substances (Dsikowitzky et al. 2015). Additionally, the use of GC $\times$ GC allowed better separation of the analytes from interferences in complex samples without extensive sample preparation (Blum et al. 2017). The disadvantage of GC-MS application is that it requires a time-consuming derivatization step, during which there are risks of analyte losses (Nikolaou 2013). For identification of non-target compounds present in the treated wastewater a mass spectrometry scanning mode full-scan mode can be applied. Another method used, often for quantitative determination, is selected ion monitoring (SIM). The main advantage of the full-scan mode over the SIM mode is the possibility of simultaneous identification of various eluted compounds that could be of interest (Gómez et al. 2009). A major disadvantage is that, generally, the full-scan method is less sensitive than SIM mode, although new generation equipment yields sufficient sensitivity (Gómez et al. 2009). Considerable problems are also attributed to the analysis of the obtained chromatograms, as in non-target screening, in which often no initial information on the analytes is available, automated peak detection and spectra deconvolution algorithms are applied, which typically reveal several thousands of peaks in an individual wastewater sample (Hug et al. 2014).

\section{Environmental effects}

Environmental risks posed by substances depend on their physical and chemical speciation and affinity for solid matter and water, which can have a significant impact on their bioavailability. Furthermore, the risk for living 
organisms is also dependent on the mobility of substances and their ability to be transferred up in the food chain. In the tissues of marine organisms contaminants can be accumulated or ingested from water or suspended matter. The result is that the pollutants concentration in the tissues of living organisms may be present at levels comparable to the concentrations in the environment or even higher (bioaccumulation). The wide variation in environmental conditions in different water areas can also affect bioavailability. Among these conditions: salinity, temperature, $\mathrm{pH}$ changes, or turbidity can be distinguished. In addition to the physicochemical properties, also the sensitivity of the species can affect the ability to bioaccumulate pollutants. Different species have different potential to bioaccumulate compounds, even when they are exposed to the same levels of specific pollutants. Even individuals of one species exposed to the same concentration of contaminants in for similar period of time may not accumulate the substance at the same rate. It is associated with other factors such as age, sex, size, and physiological state of the organism (Garnaga 2012).

Information on the concentration levels of chemicals in treated effluents is insufficient to assess the risk to aquatic ecosystems. The results of chemical analysis of target and non-target compounds provide only some information about the potential hazard to humans and the environment. In addition, analysis of non-target compounds presents many difficulties for the analyst. Due to the fact that in treated sewage a complex mixture of compounds is present and also degradation and transformation products of these compounds are occurring, it is difficult to predict the effects of this type of bottom-up approach, based on criteria for individual chemicals (Fang et al. 2017). Many compounds present in treated effluents exhibit toxic properties. Therefore, the main detrimental effects of organic micropollutants are attributed to their potential acute toxicity or sub-lethal effects on the biota. Ecotoxicological studies seem to be an excellent tool for assessing the hazards arising from the presence of harmful compounds in the treated wastewater. The ecotest results reflect the actual threat to organisms occurring in certain ecosystems. What is more, they are less time consuming and do not require highly specialized analytical equipment and staff.

Ecotoxicity tests are performed on a biological sample, i.e., a representative population of a given species of organism, which is (or is not) a subject to some change/modification after exposure to the particular pollutant for a certain time. In ecotoxicological studies various bioassays, based on aquatic organisms, are used such as bacteria, algae, macrophytes, molluscs, crustacean, and fish. It is recommended to perform several tests incorporating various species that represent different trophic levels. The test result is based on the determination of the dose or concentration of the chemical substance inducing the specific effect on the indicator organism (e.g., $\mathrm{LC}_{50}$ lethal concentration which causes death in $50 \%$ individuals in the population, $\mathrm{EC}_{50}$-effect concentration which causes a measurable effect in $50 \%$ of individuals in population, $\mathrm{IC}_{50}$-inhibition concentration that causes growth suppression of 50\% of individuals in population). In Table 2, toxicity of the compounds, which were identified at the highest concentration levels in the treated wastewater (see Table 1), towards the selected indicator organisms is given. This group of compounds is mainly dominated by pharmaceuticals.

The highest toxicity to Pseudokirchneriella subcapitata microalgae was noted for citalopram and naproxen, while for gabapentin, valsartan, irbesartan, and acetaminophen it was the lowest. High sensitivity to naproxen and its compounds also show Vibrio fischeri bacteria, Hydra attenuate, and Lemna minor. A source of high toxicity to Lemna minor was also diclofenac and benzotriazole. However, acesulfame is not toxic to Lemna minor.

Acetaminophen exhibits high toxicity to Daphnia magna, whereas its toxicity to the bacteria Vibrio fischeri is low. In turn, gabapentin manifests low toxicity with respect to all the examined indicator organisms. Vibrio fischeri bacteria are also sensitive for diclofenac but responsive to metronidazole (see Table 2). Studies reported that X-ray contrast media (i.e., iopromide, iopamidol) did not pose risk to aquatic organisms at environmentally relevant concentrations; however, data on combined toxic effects between X-ray contrast media and other substances present in environment are still scarce (Haiß and Kümmerer 2006; Tran et al. 2018).

Many of the compounds identified in wastewater have the potential to disrupt endocrine processes. Endocrinedisrupting chemicals (EDCs) are substances naturally or anthropogenically occurring in the environment. According to the definition, adopted by World Health Organization (WHO), they are exogenous compounds or mixtures with properties to change the function of the endocrine system, which will result in negative consequences on the organism, its progeny, or subpopulations. These compounds belong to different chemical families, and are able to interfere with the hormonal system of exposed organisms by mimicking or counteracting natural hormones (Huerta et al. 2016). It has been estimated that from hundreds of thousands of presently produced compounds around 1000 of them may have endocrine-disrupting properties (Gore et al. 2014). Those compounds include mainly polychlorinated biphenyls (PCBs), bisphenol A, phthalates, pesticides, some pharmaceuticals, brominated flame retardants, and organic tin compounds (Kima et al. 2015). The standard method for biological treatment of wastewater used in a typical wastewater treatment results in only partial 


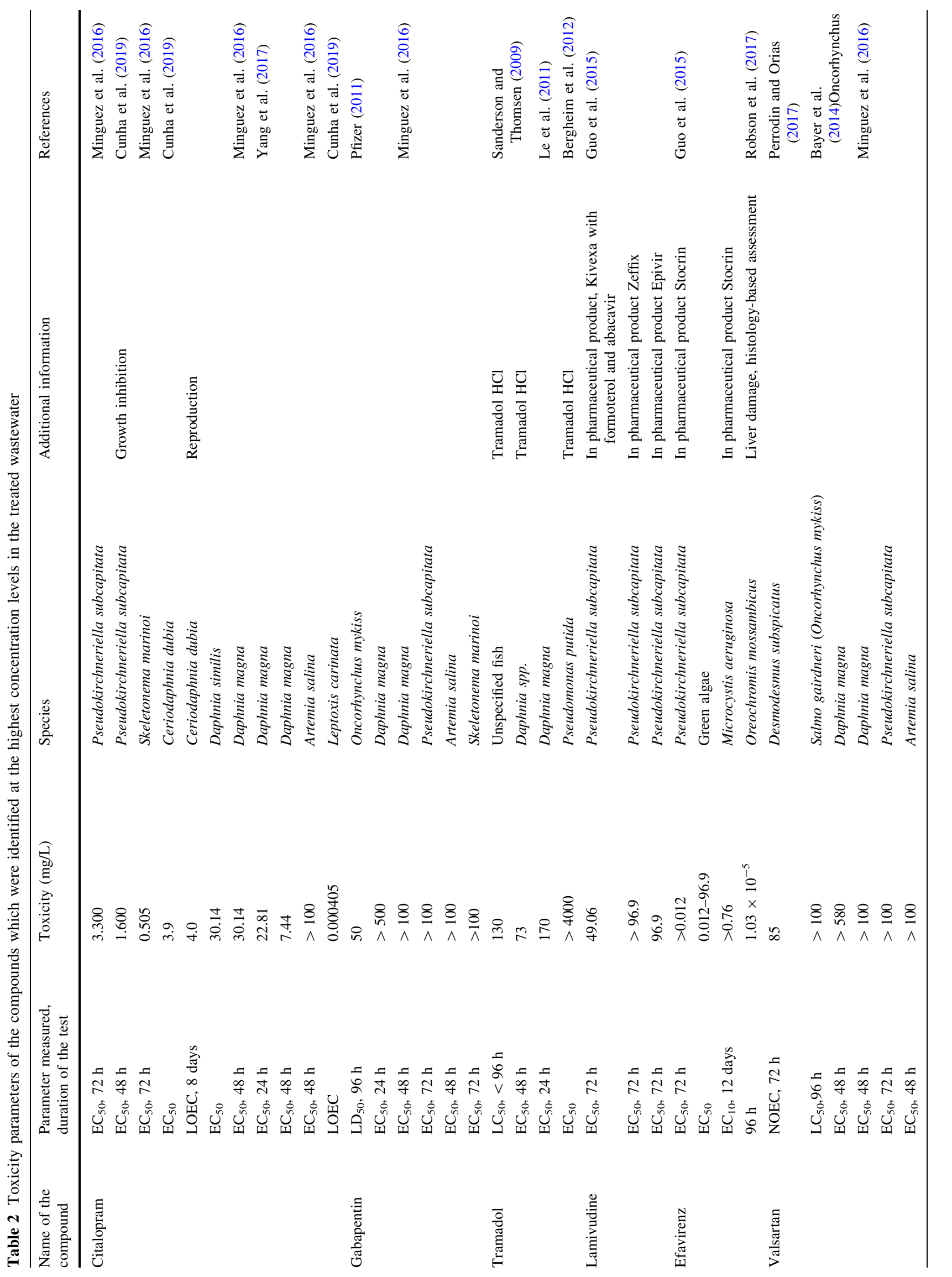




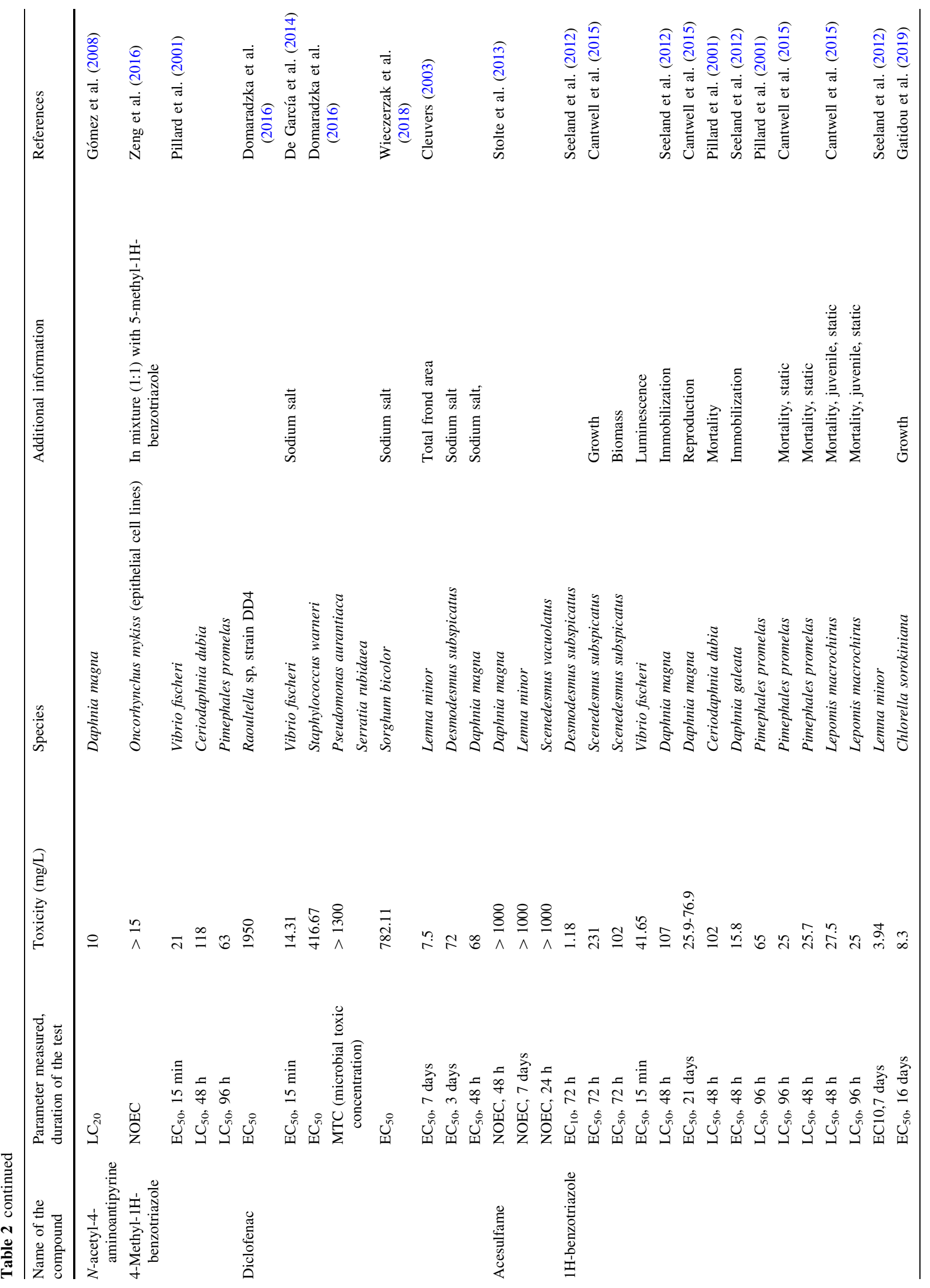




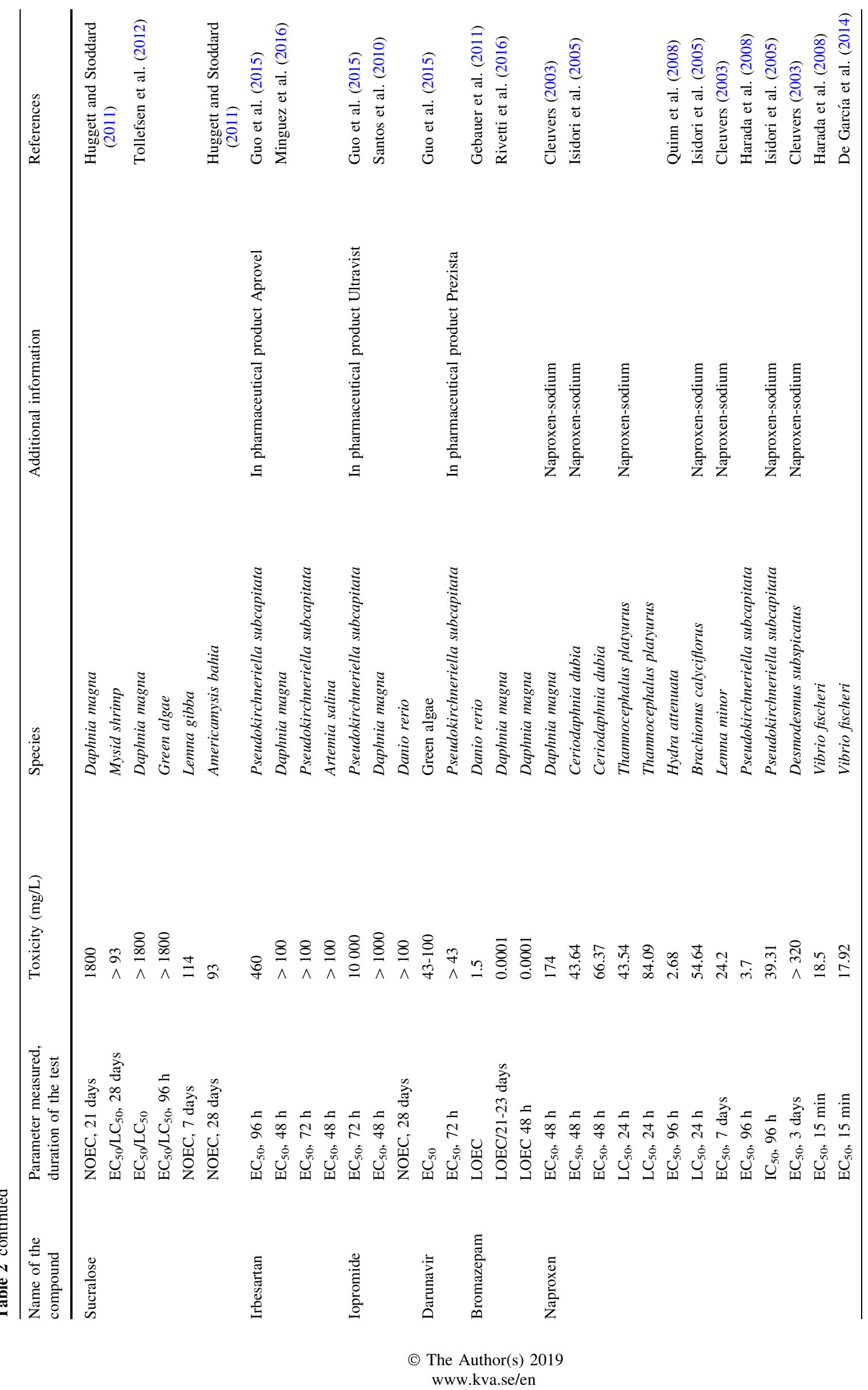




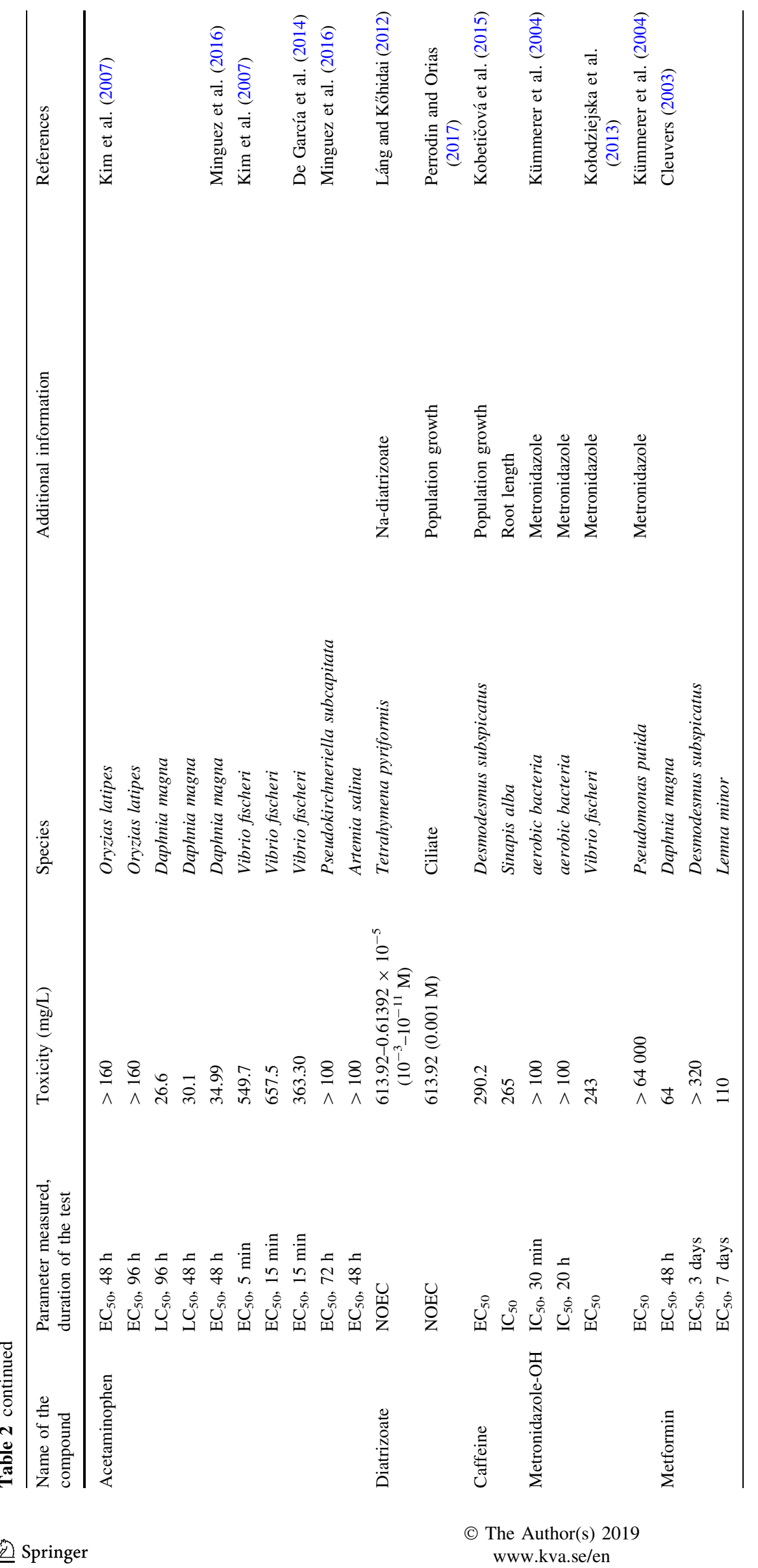


removal of the compounds from the group of EDCs, mainly of polar nature (Välitalo et al. 2016). EDCs are detected both in surface and ground waters. This phenomenon is alarming due to the fact that those compounds, when released into the water, may adversely affect living organisms, even if they occur at low levels (Kima et al. 2015). There are many literature reports which indicate that EDCs can cause adverse effects on the aquatic environment even at low concentrations. For example, studies have shown that Zebrafish were sensitive to estradiol at a very low concentration of $0.2 \mathrm{ng} / \mathrm{L}$ (Westerlund et al. 2000). The EDCs compounds identified in treated effluents include phthalate compounds such as bis (2-ethylhexyl) benzene-1,2-dicarboxylate (DEHP) and benzyl butyl benzene-1,2-dicarboxylate (BBP) and phenols such as 4-tertoctylphenol and bisphenol A (BPA). These compounds are included at the European Commission priority lists of 66 endocrine active substances for which clear evidence of endocrine-disrupting activity is confirmed (Category I) (EC 2016).

An alternative for classical analytical methods for the determination of endocrine active substances are endocrine tests. These bioassays can thus be used to determine total estrogenic activities in (extracts of) environmental samples, without the necessity of knowing all compounds present that contribute to the activity (Houtman et al. 2007). The most commonly used tests include reporter gene assays such as the yeast estrogen/androgen screen (YES/YAS), which allows identification of both, the activation (agonist) or inhibiting (antagonist) properties in samples of wastewater or estrogen receptor-mediated chemical-activated luciferase gene expression (ER-CALUX ${ }^{\circledR}$ ) assay (Houtman et al. 2007).

Exposure to chemical substances may cause damage of the genetic material of the organisms. Genotoxic compounds acting directly or indirectly on the body have the potential for altering the organism's genetic code. In addition, such compounds can induce changes not only within one generation. Effects of their action can be observed over an extended period of time, across the whole population. Therefore, it is important to carry out genotoxicity studies, especially in the case if a particular ecosystem is exposed to the constant supply of pollutants.

EDCs in wastewater effluents may be leached from microplastics (Anderson et al. 2016). Microplastics pollution is a high and increasing concern in European Union (SAM 2018). The term microplastics refers to the group of organic polymers derived from various petroleum compounds with the upper size limit of $5 \mathrm{~mm}$. Studies indicated that wastewater treatment plants (WWTPs) play an important role in releasing microplastics to the environment. The growing concerns about microplastics presence in wastewater effluents and subsequently in marine environment have been attributed to their ubiquity, long residence times accompanied by difficult removing, possibility of being assimilated by living organisms, and thus entering trophic levels as well as easiness to undergo numerous transformations during wastewater treatment process (Anderson et al. 2016; Sun et al. 2019). WWTP are not designed to fully remove microplastics, and its removal depends on the treatment process applied; however, in most cases it exceeds $80-90 \%$. An average microplastics concentrations reviewed in literature is in the range of $0-447$ particles/L (Sun et al. 2019).

\section{CONCLUSION}

Over the last years, the issue of water quality has gained strategic importance, both in the European Union and internationally. The challenge of the present day is to protect effectively aquatic ecosystems, to preserve their good condition and to reduce negative impacts on human health. The purpose of wastewater treatment plant is to remove compounds that may have adverse effects on the environment and on human health, but as the research shows the processes used in wastewater treatment are insufficient. As a result, compounds potentially hazardous may enter the surface waters. Legislation aimed at eliminating/reducing emissions to the environment are restricted to a narrow spectrum of chemicals. Most of the compounds remain beyond the legal norms.

As we have shown in our paper, the interest in the presence of micropollutants in wastewater has been reflected in the research carried out. Studies on the quality evaluation of treated effluents are carried out in a number of research centers around the world. They mainly focus on the determination of the target compounds and relate to pharmaceuticals such as analgesic/anti-inflammatories or antibiotics. Carried out literature review on the highest concentrations of contaminants in treated effluents indicates that they are observed for analgesic/anti-inflammatory drugs, i.e., diclofenac, tramadol naproxen, antiretroviral agents, industrial chemicals, or contrast media. These compounds occur at levels of several tens of $\mu \mathrm{g} / \mathrm{L}$. Although the number of studies on the determination of target pollutants in the treated wastewater is constantly increasing, there are few reports in literature on the identification of non-target compounds present in the treated wastewater. This is primarily due to the fact that such research is time consuming, requires a variety of analytical techniques, often complex or costly and sophisticated equipment. The classical methodology for assessing the environmental impact of xenobiotics, which is required by legislation, is based on the use of chemical analysis techniques, which allow to determine the concentrations of 
pollutants in environmental samples. However, the thus obtained results do not adequately reflect the risks to ecosystems and subsequently humans. On the basis of chemical analysis, the possible interactions between toxic substances and their mixture effects on living organisms cannot be determined. Therefore, the methodology for assessing the quality of treated wastewater should include, in addition to chemical analyses, ecotoxicological, genotoxic/mutagenic, or endocrine activity studies. In this way, comprehensive information on the hazard arising from the presence of all known and unknown hazardous substances in the treated wastewater is needed. Moreover, it should be noted that during wastewater treatment various by-products, of unknown properties and toxicity may be formed. Therefore, when developing new, more effective methods of wastewater treatment, it is necessary to evaluate the toxicity of the resulting products. What is more, the indicator organisms selected for ecotoxicity evaluation should be from different trophic levels as various organisms may exhibit a diverse sensitivity to the compounds, e.g., naproxen is highly toxic to Hydra attenuata and its toxicity to Daphnia magna is low. Researchers from the Institute for Inland Water Management and Water Treatment (RIZA) have already mentioned the need for a comprehensive assessment of waste water quality in the 1990s. A method for whole-effluent assessment contained a series of tests to make (potential) effects visible, focusing on the following five parameters: acute and chronic toxicity, bioaccumulation, mutagenicity, and persistence.

The problem of occurrence of potentially hazardous compounds in wastewater and surface waters to which wastewater is being discharged has been observed in many countries. The first country in which legal regulations were issued, mandating the implementation of the subsequent stage of sewage treatment intended to remove the micropollutants is Switzerland. Similar actions have been taken in Germany. Therefore, it seems that the introduction of wastewater treatment technology of micropollutants removal in other European countries is only a matter of time.

Open Access This article is distributed under the terms of the Creative Commons Attribution 4.0 International License (http:// creativecommons.org/licenses/by/4.0/), which permits unrestricted use, distribution, and reproduction in any medium, provided you give appropriate credit to the original author(s) and the source, provide a link to the Creative Commons license, and indicate if changes were made.

\section{REFERENCES}

Abafe, O.A., J. Späth, J. Fick, S. Jansson, C. Buckley, A. Stark, B. Pietruschka, and B.S. Martincigh. 2018. LC-MS/MS determination of antiretroviral drugs in influents and effluents from wastewater treatment plants in KwaZulu-Natal, South Africa. Chemosphere 200: 660-670.

Amy-Sagers, C., K. Reinhardt, and D.M. Larson. 2017. Ecotoxicological assessments show sucralose and fluoxetine affect the aquatic plant, Lemna minor. Aquatic Toxicology 185: 76-85.

Anderson, J.C., B.J. Park, and V.P. Palace. 2016. Microplastics in aquatic environments: Implications for Canadian ecosystems. Environmental Pollution 218: 269-280.

Archer, E., B. Petrie, B. Kasprzyk-Hordern, and G.M. Wolfaardt. 2017. The fate of pharmaceuticals and personal care products (PPCPs), endocrine disrupting contaminants (EDCs), metabolites and illicit drugs in a WWTW and environmental waters. Chemosphere 174: 437-446.

Asthana, A.N. 2014. Thirty years after the cataclysm: Toxic risk management in the chemical industry, American-Eurasian. The Journal of Toxicological Sciences 1: 1401-1408.

Bayer, A., R. Asner, W. Schüssler, W. Kopf, K. Weiß, M. Sengl, and M. Letzel. 2014. Behavior of sartans (antihypertensive drugs) in wastewater treatment plants, their occurrence and risk for the aquatic environment. Environmental Science and Pollution Research 21: 10830-10839.

Bergheim, M., R. Gieré, and K. Kümmerer. 2012. Biodegradability and ecotoxicitiy of tramadol, ranitidine, and their photoderivatives in the aquatic environment. Environmental Science and Pollution Research 19: 72-85.

Blum, K.M., P.L. Andersson, G. Renman, L. Ahrens, M. Gros, K. Wiberg, and P. Haglund. 2017. Non-target screening and prioritization of potentially persistent, bioaccumulating and toxic domestic wastewater contaminants and their removal in on-site and large-scale sewage treatment plants. Science of the Total Environment 575: 265-275.

Cantwell, M.G., J.C. Sullivan, and R.M. Burgess. 2015. Benzotriazoles: History, environmental distribution, and potential ecological effects. In Comprehensive analytical chemistry, ed. G. Svehla, 513-545. Amsterdam: Elsevier.

Cleuvers, M. 2003. Aquatic ecotoxicity of pharmaceuticals including the assessment of combination effects. Toxicology Letters 142: 185-194.

Corominas, L., V. Acuña, A. Ginebreda, and M. Poch. 2013. Integration of freshwater environmental policies and wastewater treatment plant management. Science of the Total Environment 445-446: 185-191.

Cunha, D.L., M.P. Mendes, and M. Marques. 2019. Environmental risk assessment of psychoactive drugs in the aquatic environment. Environmental Science and Pollution Research 26: 78-90.

Das, S., N.M. Ray, J. Wan, A. Khan, T. Chakraborty, and M.B. Ray. 2017. Micropollutants in wastewater: Fate and removal processes. IntechOpen: In Physico-Chemical Wastewater Treatment and Resource Recovery.

Dasenaki, M.E., and N.S. Thomaidis. 2015. Multianalyte method for the determination of pharmaceuticals in wastewater samples using solid-phase extraction and liquid chromatography-tandem mass spectrometry. Analytical Bioanalytical Chemistry 407: $4229-4245$.

De García, S.A.O., G.P. Pinto, P.A. García-Encina, and R. IrustaMata. 2014. Ecotoxicity and environmental risk assessment of pharmaceuticals and personal care products in aquatic environments and wastewater treatment plants. Ecotoxicology 23: $1517-1533$.

Deblonde, T., C. Cossu-Leguille, and P. Hartemann. 2011. Emerging pollutants in wastewater: A review of the literature. International Journal of Hygiene and Environmental Health 214: 442-448.

Deeb, A.A., S. Stephan, O.J. Schmitz, and T.C. Schmidt. 2017. Suspect screening of micropollutants and their transformation products in advanced wastewater treatment. Science of the Total Environment 601: 1247-1253. 
Domaradzka, D., U. Guzik, K. Hupert-Kocurek, and D. Wojcieszyńska. 2016. Toxicity of diclofenac and its biotransformation by Raoultella sp. DD4. Polish Journal of Environmental Studies 25: 2211-2216.

Dong, Z., D.B. Senn, R.E. Moran, and J.P. Shine. 2013. Prioritizing environmental risk of prescription pharmaceuticals. Regulatory Toxicology and Pharmacology 65: 60-67.

Dsikowitzky, L., O. Botalova, S. Illgut, S. Bosowski, and J. Schwarzbauer. 2015. Identification of characteristic organic contaminants in wastewaters from modern paper production sites and subsequent tracing in a river. Journal of Hazard. Materials 300: 254-262.

EC. 2016. Annex 15 List of 66 substances with classification high, medium or low exposure concern. Accessed August 19, 2018, from http://ec.europa.eu/environment/archives/docum/pdf/bkh_ annex_15.pdf.

Evgenidou, E.N., I.K. Konstantinou, and D.A. Lambropoulou. 2015. Occurrence and removal of transformation products of PPCPs and illicit drugs in wastewaters: A review. Science of the Total Environment 505: 905-926.

Fang, B., J. Guo, F. Li, J.P. Giesy, L. Wang, and W. Shi. 2017. Bioassay directed identification of toxicants in sludge and related reused materials from industrial wastewater treatment plants in the Yangtze River Delta. Chemosphere 168: 191-198.

Farré, M., S. Pérez, K. Gajda-Schrantz, V. Osorio, L. Kantiani, A. Ginebreda, and D. Barceló. 2010. First determination of C60 and C70 fullerenes and $N$-methylfulleropyrrolidine C60 on the suspended material of wastewater effluents by liquid chromatography hybrid quadrupole linear ion trap tandem mass spectrometry. Journal of Hydrology 383: 44-51.

García-Galán, M.J., M. Petrovic, S. Rodríguez-Mozaz, and D. Barceló. 2016. Multiresidue trace analysis of pharmaceuticals, their human metabolites and transformation products by fully automated on-line solid-phase extraction-liquid chromatography-tandem mass spectrometry. Talanta 158: 330-341.

Garnaga, G. 2012. Integrated assessment of pollution in the Baltic Sea. Ekologija. 58: 331-355.

Gatidou, G., P. Anastopoulou, M. Aloupi, and A.S. Stasinakis. 2019. Growth inhibition and fate of benzotriazoles in Chlorella sorokiniana cultures. Science of the Total Environment 663: 580-586.

Gebauer, D.L., N. Pagnussat, Â.L. Piato, I.C. Schaefer, C.D. Bonan, and D.R. Lara. 2011. Effects of anxiolytics in zebrafish: Similarities and differences between benzodiazepines, buspirone and ethanol. Pharmacolgy Biochemistry and Behavior 99: 480-486.

Gómez, M.J., C. Sirtori, M. Mezcua, A.R. Fernández-Alba, and A. Agüera. 2008. Photodegradation study of three dipyrone metabolites in various water systems: Identification and toxicity of their photodegradation products. Water Resources 42: 2698-2706.

Gómez, M.J., M.M. Gómez-Ramos, A. Agüera, M. Mezcua, S. Herrera, and A.R. Fernández-Albaba. 2009. A new gas chromatography/mass spectrometry method for the simultaneous analysis of target and non-target organic contaminants in waters. Journal of Chromatography A 1216: 4071-4082.

Gore, A.C., D. Crews, L.L. Doan, M. La Merrill, H. Patisaul, and A. Zota. 2014. Introduction to Endocrine Disrupting Chemicals (EDCs): A guide for public interest organizations and policymakers, Endocrine Society, December 2014. Accessed August 19, 2018, from http://www.endocrine.org/-/media/endosociety/ files/advocacy-and-outreach/important-documents/introductionto-endocrine-disrupting-chemicals.pdf.

Gros, M., K.M. Blum, H. Jernstedt, G. Renman, S. Rodríguez-Mozaz, P. Haglund, P.L. Andersson, K. Wiberg, et al. 2017. Screening and prioritization of micropollutants in wastewaters from on-site sewage treatment facilities. Journal of Hazard Materials 328: $37-45$.

Guo, J., A. Boxall, and K. Selby. 2015. Do pharmaceuticals pose a threat to primary producers? Critical Reviews in Environmental Science and Technology 45: 2565-2610.

Gurke, R., M. Roessler, C. Marx, S. Diamond, S. Schubert, R. Oertel, and J. Fauler. 2015. Occurrence and removal of frequently prescribed pharmaceuticals and corresponding metabolites in wastewater of a sewage treatment plant. Science of the Total Environment 532: 762-770.

Haiß, A., and K. Kümmerer. 2006. Biodegradability of the X-ray contrast compound diatrizoic acid, identification of aerobic degradation products and effects against sewage sludge microorganisms. Chemosphere 62: 294-302.

Harada, A., K. Komori, N. Nakada, K. Kitamura, and Y. Suzuki. 2008. Biological effects of PPCPs on aquatic lives and evaluation of river waters. Water Science and Technology 58: $1541-1546$.

HELCOM. 2003. The Baltic Marine Environment 1999-2002. Baltic Sea Environment Proceedings No. 88. Accessed August 19, 2018, from http://helcom.fi/Lists/Publications/BSEP87.pdf.

Houtman, C.J., E.G. Pim, P.E.G. Leonards, W. Kapiteijn, J.F. Bakker, A. Brouwer, M.H. Lamoree, J. Legler, et al. 2007. Sample preparation method for the ER-CALUX bioassay screening of (xeno-)estrogenic activity in sediment extract. Science of the Total Environment 386: 134-144.

Hrubik, J., B. Glisic, A. Tubic, I. Ivancev-Tumbas, R. Kovacevic, D. Samardzija, N. Andric, and S. Kaisarevic. 2016. Toxicological and chemical investigation of untreated municipal wastewater: Fraction-and species-specific toxicity. Ecotoxicology and Environmental Safety 127: 153-162.

Hu, X., C. Ren, W. Kang, L. Mu, X. Liu, X. Li, T. Wang, and Q. Zhou. 2018. Characterization and toxicity of nanoscale fragments in wastewater treatment plant effluent. Science of the Total Environment 626: 1332-1341.

Huerta, B., S. Rodriguez-Mozaz, C. Nannoua, L. Nakis, A. Ruhí, V. Acuña, S. Sabater, and D. Barcelo. 2016. Determination of a broad spectrum of pharmaceuticals and endocrine disruptors in biofilm from a waste water treatment plant-impacted river. Science of the Total Environment 540: 241-249.

Hug, Ch., N. Ulrich, T. Schulze, W. Brack, and M. Krauss. 2014. Identification of novel micropollutants in wastewater by a combination of suspect and nontarget screening. Environmental Pollution 184: 25-32.

Huggett, D.B., and K.I. Stoddard. 2011. Effects of the artificial sweetener sucralose on Daphnia magna and Americamysis bahia survival, growth and reproduction. Food and Chemical Toxicology 49: 2575-2579.

Isidori, M., M. Lavorgna, A. Nardelli, A. Parella, L. Previtera, and M. Rubino. 2005. Ecotoxicity of naproxen and its phototransformation products. Science of the Total Environment 348: 93-101.

Jiang, J.Q., Z. Zhou, and V.K. Sharma. 2013. Occurrence, transportation, monitoring and treatment of emerging micro-pollutants in waste water-A review from global views. Microchemical Journal 110: 292-300.

Kårelid, V., G. Larsson, and B. Björlenius. 2017. Pilot-scale removal of pharmaceuticals in municipal wastewater: Comparison of granular and powdered activated carbon treatment at three wastewater treatment plants. Journal of Environmental Management 193: 491-502.

Kim, Y., K. Choi, J. Jung, S. Park, P.G. Kim, and J. Park. 2007. Aquatic toxicity of acetaminophen, carbamazepine, cimetidine, diltiazem and six major sulfonamides, and their potential ecological risks in Korea. Environmental International 33: 370-375. 
Kima, K.-H., E. Kabir, and S. Kabir. 2015. Response to correspondence of associating airborne particulates and human health: Exploring possibilities. Environment International 82: 114.

Knopp, G., C. Prasse, T.A. Ternes, and P. Cornel. 2016. Elimination of micropollutants and transformation products from a wastewater treatment plant effluent through pilot scale ozonation followed by various activated carbon and biological filters. Water Resources 100: 580-592.

Kobetičová, K., G. Losonszky, O. Pařízek, and V. Kočí. 2015. Effects of caffeine on plants. Vliv abiotických a biotických stresorů na vlastnosti rostlin. Sborník recenzovaných vědeckých prací, $166-168$.

Kołodziejska, M., J. Maszkowska, A. Białk-Bielinska, S. Steudte, J. Kumirska, P. Stepnowski, and S. Stolte. 2013. Aquatic toxicity of four veterinary drugs commonly applied in fish farming and animal husbandry. Chemosphere 92: 1253-1259.

Kotowska, U., K. Biegańska, and V.A. Isidorov. 2012. Screening of trace organic compounds in municipal wastewater by gas chromatography-mass spectrometry. Polish Journal of Environmental Studies 21: 129-138.

Kotowska, U., J. Kapelewska, and J. Sturgulewska. 2014. Determination of phenols and pharmaceuticals in municipal wastewaters from Polish treatment plants by ultrasound-assisted emulsification-microextraction followed by GC-MS. Environmental Science and Pollution Research 21: 660-673.

Kümmerer, K., R. Alexey, J. Hüttig, and A. Schöll. 2004. Standardized tests fail to assess the effects of antibiotics on environmental bacteria. Water Resources 38: 2111-2116.

Láng, J., and L. Köhidai. 2012. Effects of the aquatic contaminant human pharmaceuticals and their mixtures on the proliferation and migratory responses of the bioindicator freshwater ciliate Tetrahymena. Chemosphere 89: 592-601.

Le, T.H., E.S. Lim, S.K. Lee, J.S. Park, Y.H. Kim, and J. Min. 2011. Toxicity evaluation of verapamil and tramadol based on toxicity assay and expression patterns of Dhb, Vtg, Arnt, CYP4, and CYP314 in Daphnia magna. Environmental Toxicology 26: 515-523.

Luo, Y., W. Guo, H.H. Ngo, L.D. Nghiem, F.I. Hai, J. Zhang, S. Liang, X.C. Wang. 2014. A review on the occurrence of micropollutants in the aquatic environment and their fate and removal during wastewater treatment. Science of the Total Environment 473: 619-641.

Madeła, M., E. Neczaj, and A. Grosser. 2016. Fate of engineered nanoparticles in wastewater treatment plant. Inżynieria $i$ Ochrona Środowiska 19: 577-587.

Madikizela, L.M., and L. Chimuka. 2017. Occurrence of naproxen, ibuprofen, and diclofenac residues in wastewater and river water of KwaZulu-Natal Province in South Africa. Environmental Monitoring Assessment 189: 348.

Minguez, L., J. Pedelucq, E. Farcy, C. Ballandonne, H. Budzinski, and M.-P. Halm-Lemeille. 2016. Toxicities of 48 pharmaceuticals and their freshwater and marine environmental assessment in northwestern France. Environmental Science and Pollution Research 23: 4992-5001.

Ngumba, E. 2018. Occurrence and control of selected antibiotics and antiretroviral drugs in urban hydrological cycles. Accessed May 8, 2019, from https://jyx.jyu.fi/bitstream/handle/123456789/ 56979/978-951-39-7344-5_vaitos16022018.pdf?sequence=1.

Nikolaou, A. 2013. Pharmaceuticals and related compounds as emerging pollutants in water: Analytical aspects. Global NEST Journal 15: 1-12.

Oliveira, T.S., M. Murphy, N. Mendola, V. Wong, D. Carlson, and L. Waring. 2015. Characterization of pharmaceuticals and personal care products in hospital effluent and waste water influent/effluent by direct-injection LC-MS-MS. Science of the Total Environment 518-519: 459-478.
Papageorgiou, M., C. Kosma, and D. Lambropoulou. 2016. Seasonal occurrence, removal, mass loading and environmental risk assessment of 55 pharmaceuticals and personal care products in a municipal wastewater treatment plant in Central Greece. Science of the Total Environment 543: 547-569.

Perrodin, Y., and F. Orias. 2017. Ecotoxicity of Hospital Wastewater. Hospital Wastewaters, 33-47. Cham: Springer.

Petrie, B., R. Barden, and B. Kasprzyk-Hordern. 2015. A review on emerging contaminants in wastewaters and the environment: Current knowledge, understudied areas and recommendations for future monitoring. Water Resources 72: 3-27.

Petrie, B., K. Proctor, J. Youdan, R. Barden, and B. KasprzykHordern. 2017. Critical evaluation of monitoring strategy for the multi-residue determination of 90 chiral and achiral micropollutants in effluent wastewater. Science of the Total Environment 579: $569-578$

Pfizer. 2011. Material safety data sheet for neurontin (gabapentin) oral solution. Accessed August 19, 2018, from http://www. pfizer.com/system/files/products/material_safety_data/ Neurontin_Oral_Solution_02-Mar-2011.pdf.

Pillard, D.A., J.S. Cornell, D.L. DuFresne, and M.T. Hernandez. 2001. Toxicity of benzotriazole and benzotriazole derivatives to three aquatic species. Water Resources 35: 557-560.

Qi, W., H. Singer, M. Berg, B. Müller, B. Pernet-Coudrier, H. Liu, and J. Qu. 2015. Elimination of polar micropollutants and anthropogenic markers by wastewater treatment in Beijing, China. Chemosphere 119: 1054-1061.

Quinn, B., F. Gagné, and C. Blaise. 2008. An investigation into the acute and chronic toxicity of eleven pharmaceuticals (and their solvents) found in wastewater effluent on the cnidarian, Hydra attenuate. Science of the Total Environment 389: 306-314.

Ratola, N., A. Cincinelli, A. Alves, and A. Katsoyiannis. 2012. Occurrence of organic microcontaminants in the wastewater treatment process. A mini review. Journal of Hazard. Materials 239: 1-18.

Ribbers, K., L. Breuer, and R.A. Düring. 2019. Detection of artificial sweeteners and iodinated X-ray contrast media in wastewater via LC-MS/MS and their potential use as anthropogenic tracers in flowing waters. Chemosphere 218: 189-196.

Ribeiro, C., A.R. Ribeiro, and M.E. Tiritan. 2016. Priority substances and emerging organic pollutants in Portuguese aquatic environment: A review. In Reviews of environmental contamination and toxicology, ed. P. de Voogt, 1-44. Cham: Springer.

Rivetti, C., B. Campos, and C. Barata. 2016. Low environmental levels of neuro-active pharmaceuticals alter phototactic behaviour and reproduction in Daphnia magna. Aquatic Toxicology 170: 289-296.

Roberts, J., A. Kumar, J. Du, C. Hepplewhite, D.J. Ellis, A.G. Christy, and S.G. Beavis. 2016. Pharmaceuticals and personal care products (PPCPs) in Australia's largest inland sewage treatment plant, and its contribution to a major Australian river during high and low flow. Science of the Total Environment 541: 1625-1637.

Robson, L., I.E.J. Barnhoorn, and G.M. Wagenaar. 2017. The potential effects of efavirenz on Oreochromis mossambicus after acute exposure. Environmental Toxicology and Pharmacology 56: 225-232.

SAM. 2018. Microplastic pollution: The policy context-background paper. The Scientific Advice Mechanism Unit of the European Commission, pp. 1-68.

Sanderson, H., and M. Thomsen. 2009. Comparative analysis of pharmaceuticals versus industrial chemicals acute aquatic toxicity classification according to the United Nations classification system for chemicals. Assessment of the (Q)SAR predictability of pharmaceuticals acute aquatic toxicity and their predominant acute toxic mode-of-action. Toxicology Letters 187: 84-93. 
Santos, L.H., A.N. Araújo, A. Fachini, A. Pena, C. Delerue-Matos, and M.C.B.S.M. Montenegro. 2010. Ecotoxicological aspects related to the presence of pharmaceuticals in the aquatic environment Journal of Hazard. Materials 175: 45-95.

Seeland, A., M. Oetken, A. Kiss, E. Fries, and J. Oehlmann. 2012. Acute and chronic toxicity of benzotriazoles to aquatic organisms. Environmental Science and Pollution Research 19: 1781-1790.

Stolte, S., S. Steudte, N.H. Schebb, I. Willenberg, and P. Stepnowski. 2013. Ecotoxicity of artificial sweeteners and stevioside. Environmental International 60: 123-127.

Sun, J., X. Dai, Q. Wang, M.C. van Loosdrecht, and B.J. Ni. 2019. Microplastics in wastewater treatment plants: Detection, occurrence and removal. Water Research 152: 21-37.

Tollefsen, K.E., L. Nizzetto, and D.B. Huggett. 2012. Presence, fate and effects of the intense sweetener sucralose in the aquatic environment. Science of the Total Environment 438: 510-516.

Tolouei, S., J.B. Burnet, L. Autixier, M. Taghipour, J. Bonsteel, S.V. Duy, S. Sauvé, M. Prévost, et al. 2019. Temporal variability of parasites, bacterial indicators, and wastewater micropollutants in a water resource recovery facility under various weather conditions. Water Resources 148: 446-458.

Tran, N.H., M. Reinhard, and K.Y.H. Gin. 2018. Occurrence and fate of emerging contaminants in municipal wastewater treatment plants from different geographical regions-a review. Water Resources 133: 182-207.

Välitalo, P., N. Perkola, T.-B. Seiler, M. Sillanpää, J. Kuckelkorn, A. Mikola, H. Hollert, and E. Schultz. 2016. Estrogenic activity in Finnish municipal wastewater effluents. Water Resources 88: 740-749.

Völker, J., T. Vogt, S. Castronovo, A. Wick, T.A. Ternes, A. Joss, J. Oehlmann, and M. Wagner. 2017. Extended anaerobic conditions in the biological wastewater treatment: Higher reduction of toxicity compared to target organic micropollutants. Water Resources 116: 220-230.

Wang, J., Z. Tian, Y. Huo, M. Yang, X. Zheng, and Y. Zhang. 2018. Monitoring of 943 organic micropollutants in wastewater from municipal wastewater treatment plants with secondary and advanced treatment processes. Journal of Environmental Sciences 67: 309-317.

Westerlund, L., K. Billsson, P.L. Andersson, M. Tysklind, and P.-E. Olsson. 2000. Early life-stage mortality in zebrafish (Danio rerio) following maternal exposure to polychlorinated biphenyls and estrogen. Environmental Toxicology and Chemistry 19: $1582-1588$.

WFD. 2000. Directive 2000/60/EC of the European Parliament and of the Council of 23 October 2000 establishing a framework for Community action in the field of water policy. Official Journal of the European Communities, L 327, 22 December 2000.

Wieczerzak, M., B. Kudłak, and J. Namieśnik. 2018. Impact of selected drugs and their binary mixtures on the germination of Sorghum bicolor (sorgo) seeds. Environmental Science and Pollution Research 25: 18717-18727.

Yang, Y., Q. Chen, J.D. Wall, and Z. Hu. 2012. Potential nanosilver impact on anaerobic digestion at moderate silver concentrations. Water Research 46: 1176-1184.

Yang, Y., Y.S. Ok, K.H. Kim, E.E. Kwon, and Y.F. Tsang. 2017. Occurrences and removal of pharmaceuticals and personal care products (PPCPs) in drinking water and water/sewage treatment plants: A review. Science of the Total Environment 596: 303-320.

Zeng, F., J.P. Sherry, and N.C. Bols. 2016. Use of the rainbow trout cell lines, RTgill-W1 and RTL-W1 to evaluate the toxic potential of benzotriazoles. Ecotoxicology and Environmental Safety 124: 315-323.

Publisher's Note Springer Nature remains neutral with regard to jurisdictional claims in published maps and institutional affiliations.

\section{AUTHOR BIOGRAPHIES}

Justyna Rogowska $(\bowtie)$ is an Assistant Professor at the Medical University of Gdansk. She has a habilitation in the health sciences and a $\mathrm{Ph} . \mathrm{D}$. degree in chemistry. Moreover, she graduated from the University of Gdansk with the master of art degree in law. Her major research interests include environmental chemistry (especially monitoring and analysis of environmental pollutants) and ecotoxicology (with particular emphasis on the water environment), especially correlations between physicochemical and ecotoxicological properties of environmental xenobiotics. In addition, research interests concern the legal aspects of environmental protection, in particular marine environmental protection.

Address: Department of Environmental Toxicology, Faculty of Health Sciences, Medical University of Gdansk, Debowa Str. 23A, 80-204 Gdansk, Poland.

e-mail: justyna.rogowska@gumed.edu.pl

Monika Cieszynska-Semenowicz is an Assistant Professor at the Medical University of Gdansk. She has a Ph.D. degree in pharmacy. She is a specialist in ecotoxicology.

Address: Department of Environmental Toxicology, Faculty of Health Sciences, Medical University of Gdansk, Debowa Str. 23A, 80-204 Gdansk, Poland.

e-mail: monika.cieszynska-semenowicz@gumed.edu.pl

Wojciech Ratajczyk has a Ph.D. in the health sciences. His research interests include marine environment pollution resulting from the emission of treated wastewater from wastewater treatment plants. This issue was the scope of his doctoral dissertation.

Address: Department of Environmental Toxicology, Faculty of Health Sciences, Medical University of Gdansk, Debowa Str. 23A, 80-204 Gdansk, Poland.

e-mail: sinclair@gumed.edu.pl

Lidia Wolska is a Head of Department of Environmental Toxicology (Medical University of Gdansk) and a Full Professor in chemistry. She is a specialist in the field of analytical chemistry, environmental chemistry, and ecotoxicology. She is author or co-author of more than 400 publications (including 98 papers in journals on the ISI Master Journal List with a total impact factor of $\Sigma \mathrm{IF}=190.438, h$-index $=20$ ).

Address: Department of Environmental Toxicology, Faculty of Health Sciences, Medical University of Gdansk, Debowa Str. 23A, 80-204 Gdansk, Poland.

e-mail: lidia.wolska@gumed.edu.pl 